\title{
THE PESANTREN-BASED RULING ELITE IN SUMENEP IN THE POST-NEW ORDER INDONESIA'
}

\author{
Abdul Gaffar Karim \\ Gadjah Mada University, Yogyakarta - Indonesia
}

\begin{abstract}
This paper discusses a dominant group in local politics of Sumenep that is based on a pesantren network that is usually referred to as the Bani Syarqawi. The author argues that the superiority of religious clerics (kyal) over the mass in Sumenep has been mainly based on their adaptability to the transformational change of their role from traditional-charismatic to rational-authoritative by means of educational excellence and genealogical network that is both powerful and full of conflict. The social significance of the superiority found its way through a social change that enabled the religious elite to be the dominant elite group in Sumenep when the power of their royal counterpart declined rapidly. Equipped with Weberian model of authority, the author argues that the formalistic tendency of elite theory can be balanced with a perspective that elite can develop and exercise power over the mass even they are outside the formal structure of politics.
\end{abstract}

Keywords: Religious elites, political recruitment, the Bani Syarqawi, kyai, pesantren.

\section{Introduction}

The existing polities may have various styles of power relation (such as 'democratic', 'authoritarian', 'semi-authoritarian', 'quasi-democracy', and many others). However, all of them have one thing in common: the existence of larger number of mass on the one hand, and the smaller number of ruling persons on the other hand. The notions of elite with significant role in their communities have always been the

\footnotetext{
${ }^{1}$ I wish to thank to an anonymous reader for constructive comments on the earlier draft of this paper.
} 
central theme in political science. Studies of democracy, authoritarianism, bureaucracy, social institutions, elections, and so forth, are actually looking at the dynamics of elite in the societies from various approaches, theoretical backgrounds, and methodological standings. People witness some paradigmatic switch in political science, ${ }^{2}$ such as from individual perspective to institutional determination, but the discipline has always had central passion of elite issues. Politics, nonetheless, is all about power: how people gain and use power and how they keep it on their hands. Or, how people become and remain the elite of their societies.

This notion is also true in the case of transition from authoritarian regime, with the result varying from the sunrise of democratic polity to simply circulation of people in power. Studying the transition process would to a very large extent mean looking at how elite-mass relations changes take shape. Indonesia, a country with an ongoing political transition since the demise of President Soeharto and his military backed regime in $1998,{ }^{3}$ has never been any exception to this. The analysis of Indonesian political change would also require, among other aspects, a great deal of understanding of the elite circulations both nationally and locally. While Indonesian elite at national level have received sufficient attention from observers, ${ }^{4}$ the local elite have never enjoyed that kind of luxury. This paper is intended to fill in the gap, by looking at ruling elite at local level. It takes a case study of

2 See for instance Colin Hay, Political Analysis: A Critical Introduction (New York: Palgrave, 2002).

${ }^{3}$ Indonesian politics since 1998 has been discussed by so many academics. See for examples, Damien Kingsbury and Arief Budiman (eds), Indonesia: The Uncertain Transition (Adelaide: Crawford Publishing, 2001); Mikaela Nyman, Democratising Indonesia: The Challenges of Civil Society in the Era of Reformasi (Copenhagen: NIAS, 2006); Olle Törnquist, "Dynamics of Indonesian Democratisation," Third World Quarterly, 21, No. 3 (2000); idem., "What's Wrong with Indonesia's Democratization?," Asian Journal of Social Science, 30, No. 3 (2002).

4 For the latest accounts, see for instance Edward Aspinall, Opposing Subarto; Compromise, Resistance, and Regime Change in Indonesia (California: Stanford University Press, 2005); Rodd McGibbon, "Indonesian Politics in 2006: Stability, Compromise and Shifting Contests over Ideology," Bulletin of Indonesian Economic Studies, 42, No. 3 (2006); Dirk Tomsa, "The Defeat of Centralized Paternalism: Factionalism, Assertive Regional Cadres, and the Long Fall of Golkar Chairman Akbar Tandjung," Indonesia, 81 (2006). The most outstanding, pioneer studies of Indonesian elite can be found in Donald K. Emmerson, Indonesia's Elite: Political Culture and Cultural Politics (Ithaca: Cornell University Press, 1976). 
pesantren-based ${ }^{5}$ ruling elite in an Indonesian coastal town of Sumenep known as the Bani Syarqawi, and shows that religious elite is a ruling class who uses its power with impressive flexibility. ${ }^{6}$

\section{Ruling Elite: Theoretical Assumptions}

Elite theory is one of the core theoretical pillars in social and political sciences. This theory sees society as divided into two groups, i.e. the ruling minority (elite) and the majority who are ruled by the minority. There are two main characteristics of elite theory. First, elite theory pays greater attention to national elite, ${ }^{7}$ and second, elite theory refers to elite as the small number of people who hold formally institutionalised power within their community. ${ }^{8}$

The classical elite theory is attributed to (among others) Pareto, Mosca, and Michels. ${ }^{9}$ They shared a common view that egalitarian ideas such as democracy was not realistic, because political power would always be exercised by small number of people with great privileges. For Mosca, resources of power are never distributed equally, and thus a cohesive minority will always be able to control the incoherent majority. The reason of inequality of power distribution is, according to Pareto, to be found in the unequal physical, intellectual, and moral quality of people. Those with the higher quality would become the elite with power to manipulate the mass. With a slightly different line of argument, Michels maintained that within all organisations, power would be centralised in the hands of small dominant groups that were able to control the larger part of organisation. Michels called this the iron law of oligarchy.

In the more recent era, Mills and Dye are amongst the widely respectable elite theorists. They built their theoretical elaboration based

\footnotetext{
5 Pesantren is traditional Islamic boarding school, the student of which is called santri.

${ }^{6}$ Bani literally means the 'descendant of'; and the Bani Syarqawi would literally means the descendants of Syarqawi. This term sometimes also refers to the extended network of the santri of Syarqawi's pesantren.

7 Eva Etzioni-Halevy, "Network Governance as a Challange to Democratic Elite Theory," (Paper presented at the Conference on Democratic Network Governance, Copenhagen, May 22-23, 2003), p. 4; H. T. Reynolds, "The Power Elite," (http://www.socialstudieshelp.com/APGOV_Power_Elite.htm, created 1996).

${ }^{8}$ D. Ali Arslan, "Elite Theory Applied to Contemporary Turkish Society," International Journal of Human Science, 2, No. 2 (2005), p. 3.
}

${ }^{9}$ Andrew Heywood, Politics (New York: Palgrave, 2002). 
on America's national elite, and both argue that America is controlled by small number of people. ${ }^{10}$ Dye maintain that people occupying the upper echelons of the country leadership control the vast majority of economic resources, industrial assets, academic institutions, private foundations, and so forth. Earlier than Dye, Mills has argued that three groups of people dominated the governing elite of America. These groups are the highest political leaders including the president and a handful of key cabinet members and close advisers, major corporate owners and directors, and high-ranking military officers. Known as power elite theory, Mills' and Dye's perspective depicts the elite as a coherent entity.

The national and formal tendencies in elite theory may make it somewhat unfit to the need of analysis of elite at local level with more non-formal institutional bases. However, even if that is really the case, some analytical devices in the elite theory discussed below are apparently useful to frame the discussion of local and non-formal elites. ${ }^{11}$ First and perhaps the most important aspect of elite is their superiority over the mass. The degree of elite superiority, and how they exercise it, may vary from one society to another, but there is no doubt that elite superiority does exist. The notion of elite superiority is also related to what is known as the relative autonomy of elite. Both classical and modern elite theories agree that economic standing is one of the strongest bases for elite superiority. With strong economic power on their hand, elite members would be able to develop their influence over the mass. Another important pedestal for elite superiority is, referring to Pareto, intellectual and moral quality. In smaller communities where social interactions are more personal, this would be far more important than economic prominence to determine the ability of elite to control and manipulate the mass. People known for their moral and intellectual quality such as religious preachers would be the central elements of elite at this scope of community.

However, it is very important to underline that elite is based more on social institutions, not individual. Whereas the individual quality of elite members are indeed very important to support their superiority, yet the real strength of elite's social power lies in the institutional

\footnotetext{
${ }^{10}$ Ibid.; Reynolds, “The Power Elite."

11 This section will refer to Arslan, "Elite Theory"; Etzioni-Halevy, Network Governance; Heywood, Politics; Reynolds, "The Power Elite”; unless indicated otherwise.
} 
aspect--not in as sense of formal organisation, but more of the patterns and norms of social interactions in the community that the elite members are associated with. The next important aspect of elite, therefore, is the shared attitudes and beliefs among their members. The elite members would act in accordance with the set of values functioning as the guidance of behaviour on the one hand, and the expression of group identity on the other. This is how elite members may look, and emphasise that they are indeed, different from the mass. ${ }^{12}$

Another aspect is the competition amongst the elite. If the power elite perspective assumes that elite is coherent, the democratic elite theory (or competitive elite theory) sees that even among the elite members, is a very big issue, and thus rivalry amongst them is a significant aspect. There are competitions among them that lead to the pyramidal structure of elite, from a very small number of elite at the top level, to medium scale elite of a larger number, and to small scale elite that often known as sub-elite of even larger number. The competitions could even lead to fractured elite structure, where apart from the established elite there are also non-established elite groups. The competitive nature of elite also has something to do with the fact that political transition in most countries would merely mean elite circulation, or even elite transformation.

\section{Religious Elite}

Religion has both individual dimension as the guidance for human beings to 'communicate' with their Creator, and social dimension to govern the relations amongst the mortals. In the latter dimension, manifestation of religions by virtue of social structures vary from centralised and hierarchical forms such as those in Catholics and Iranian Shi'ite Muslim, to a more scattered and decentralised forms such as those in Jews and Sunnite Muslim. These structures are run by religious figures, with the role ranging from acting as the sole channel for humanity to reach the kingdom of heaven, to merely the bearer of divine teachings. Whatever the duty to which they may assign themselves, these religious figures are nonetheless members of social

\footnotetext{
12 Political science recognises the existence of elite political culture that "consists of beliefs, attitudes and ideas about politics held by those who are closest to the centres of political power." See Rod Hague and Martin Harrop, Comparative Government and Politics: An Introduction, 5th edition (New York: Palgrave, 2001), p. 86.
} 
elite who share the same characteristics with other elite, with the superiority, shared attitudes and beliefs, and competition among each other. The religious changing in modern era have never really been about the amendment of the doctrinal aspect but more about the reinterpretation of the doctrine, or more about the repositioning of religious elite and their role in the communities.

We can take secularism as the perfect example. Secularism is largely taken as separation between the state and religion. The term has its roots in a value that the state and the religion are dwellers of separate realm, and that both have different kind of power that are not supposed to interfere with each other. From secularist point of view, religion should remain part of human's individual life, and stay away from public space with all those social and political interests. What is interesting here is that secularism has one of its pillars on the elite competitions in Europe known as the anticlericalism. ${ }^{13}$ Secularism has actually been aiming at excluding the religious clerics (not necessarily the religion) from active political role. It is by all means elite competition, and may not necessarily stand on some sophisticated religious or philosophical paradigm.

However, as the secular authority "plummeted in the wake of corruption, economic failure and political repression", religion and to some extent ethnicity found the opportunity to pave the way for more active political role. ${ }^{14}$ This has been part of what generally referred to as religious revival taking place at least since 1950s, the core element of which is the redefinition of the role of religious institutions and religious elites in modern life. In Latin American states since the late 1960s, the liberation theology movement have been a good example of how religious institutions challenge the authoritarian states and the unjust social, economic, and political structures. Casanova interestingly points out the general tendency that religions have taken more the side of civil society and contributed to the democratisation process in some Latin American, Eastern European, East Asian, and South African

${ }_{13}$ Richard W. Bulliet, The Case for Islamo-Christian Civilization (New York: Columbia University Press, 2004); Michael Burleigh, Earthly Powers: The Clash of Religion and Politics in Europe from the French Revolution to the Great War (California: Harper Collins, 2006).

${ }^{14}$ Jeff Haynes, Religion in Third World Politics, Issues in Third World Politics (Colorado: Lynne Rienner, 1994). 
countries..$^{15}$ The roots of this tendency can be found in the efforts to redefine the role of religious institutions, including the Second Vatican Council Within this movement, echoed in other religious communities in varying degrees, the secularist and anticlerical practices were challenged, and religious elite found their way to more active political role.

With regards to the political role of religious elite, there are issues of legitimacy, with the question of authority being the main aspect. Using the classical Weberian perspective there are three types of authority: traditional, charismatic, and legal rational. ${ }^{16}$ Traditional authority is based on the customs and traditions that have already been in the society for long time. People obey a regime because it is regarded as already in existence with unquestionable legitimacy that has been accepted by previous generations. This type of authority can be found in small groups or communities with patriarchalism or gerontocracy, and is generally the characteristic of system of rule with hereditary transfer of power. Rulers are rulers because they have ascriptive legitimacy.

The charismatic authority is based on the personality of individual leader, assuming that legitimacy is related to a somewhat spiritual quality of the leader and therefore it often has no limit. Charismatic leaders can have devoted followers without much depending on rational reasons such as the reward and punishment system. Instead, charismatic leaderships hinge upon individual faith and trust.

Legal-rational authority is based on legally defined set of rules and would normally be found in the authority of most modern states. Here, leaders are elected or appointed not merely on ascriptive and charismatic bases, but more on the considerations of capability to govern. They are also limited by the set of rule, as to what they are able to do, and how long the can remain in power. Greater efficiency would be the characteristic of this type of authority, but Weber also feared that it would lead to depersonalised and unrelenting social environment.

15 Jose Casanova, "Civil Society and Religion: Retrospective Reflections on Catholicism and Prospective Reflections on Islam," Social Research, 68, No. 4 (2001).

16 The compilation or extraction of Weber's work in English can be found at URL's: http://www.sociosite.net/topics/weber.php and http://ssr1.uchicago.edu/PRELIMS/Theory/weber.html. 
Haynes rightly maintains that religious leaders usually have charismatic and traditional authority, and that "religion authority and civil authority are nearly always kept separate." However, in some specific cases, such as the case of Khomeini in Iran, a religious leader may also achieve the rational-legal authority. "[P]eople have turned to religious leaders as sources of authority precisely because of the absence of legitimacy and hence authority on the part of civil, secular leaders in the context of the failed expectations of modernization."17

Given the formal tendency of the elite theory as discussed above, observers may not always agree to perceive religious elite as ruling class or ruling elite. In countries where religious clerics are separated into those who stand outside the state power, and those who gain bureaucratic power from the state authority, the elite theory would only fit the latter. When trying to describe the majority of ulama as being outside state cooptation, Mansurnoor understandably says that "[u]nlike bureaucratic ulama, most ulama in Indonesia stand outside the ruling class". ${ }^{18}$ However, when we take the more generic idea of the presence of elite before the mass, as also mentioned above, we do not have to limit the application of elite theory only to those with formal power. In some traditional communities, the non-formal power never really has so much difference from formal power. The elite may posses ruling power whether or not they occupy formal position. Attributes to the power may vary such as according to the Weberian perspective, and may interchangeable one with each other as our discussion on religious elite in Sumenep would suggest.

\section{Kyai Syarqawi and An Nuqayah ${ }^{19}$}

The religious elite group that we are discussing here has it genealogical root in an ulama called kyai haji Mohammad Syarqawi (usually referred to as kyai Syarqawi). There is not much information about the early life of Syarqawi, except that he was born in Kudus, a town in the present day Central Java province, and that his father and grandfather were great ulama in the town. Syarqawi was trained in

\footnotetext{
17 Haynes, Religion in Third World, pp. 12-3.

18 Iik A. Mansurnoor, Islam in Indonesian World: Ulama of Madura (Yogyakarta: Gadjah Mada University Press, 1990), p. xvii.

${ }^{19}$ Kyai is the title given to Muslim scholars in some Indonesian communities particularly in Java and Madura.
} 
Egypt and Mecca for a couple of years after his earlier education at pesantren in Java, Madura, Kalimantan and the present day Malaysia. ${ }^{20}$ It has always been normal practices for most ulama families to send their children to excellent educational institutions, where they would study so many things from Arabic language, pedagogy, leadership, and most certainly the Islamic knowledge. This educational excellence would make the kyai very superior over their communities especially in rural areas. Sending their sons to Mecca would also give an additional status of hajj for the sons of the kyai who would surely become kyai one day. As a son of an ulama, Syarqawi was in Mecca for these reasons.

In the holy-land Syarqawi met with a rich trader who was also an ulama from Prenduan village in Sumenep, kyai Gemma. Doing the hajj pilgrimage with his wife, Gemma made good friends with Syarqawi. As the story goes, Gemma was very impressed by the young and smart Syarqawi. ${ }^{21}$ Unfortunately for Gemma, his health was not very good while doing the pilgrimage. As he was getting very sick, and felt that he might pass away in a very close future, he made his last will asking Syarqawi to marry his wife if he dies in Mecca. Before too long, Gemma passed away, and to fulfil his will, Syarqawi married his widow Khadijah.

In 1875 Syarqawi and Khadijah sailed to Sumenep, and started to settle in Prenduan, a wealthy village in the southern coast of Madura. In this village Syarqawi taught religious knowledge at a small pesantren and soon became very famous across the town. It seemed that his fastgrowing popularity made some kyai in Prenduan unhappy, and forced Syarqawi to consider moving to other place to continue his pesantren. A friend offered him a block of land with an old stable on it, in a village named Guluk-guluk, about $8 \mathrm{~km}$ due north of Prenduan. Syarqawi migrated to this village, left his pesantren in Prenduan to Chotib, a

\footnotetext{
20 One source says that Syarqawi stayed in Mecca for as long as 12 years. See H. M. Afif Hasan, "Pola Pembangunan Masyarakat Desa oleh Pondok Pesantren an Nuqayah" (Unpublished MA Thesis, IKIP Malang, 1995), p. 159.

${ }^{21}$ Huub de Jonge, Madura dalam Empat Jaman (Jakarta: Gramedia, 1989); idem., "Perkembangan Ekonomi dan Islamisasi di Madura," in Huub de Jonge (ed.), Agama, Kebudayaan, dan Ekonomi: Studi-studi Interdisipliner tentang Masyarakat Madura (Jakarta: Rajawali Press, 1989).
} 
young kyai from the village. This pesantren would later become the $\mathrm{Al}$ Amien pesantren. ${ }^{22}$

The year was 1887 when Syarqawi started a new pesantren in Gulukguluk with an old stable being his very first asset. The pesantren would later be named An Nuqayah, literally means 'the clarity' or 'the purity', referring to the title of a kital (book) written by Jalal ad-Din Al-Suyuti, containing 14 chapters on knowledge. ${ }^{23}$

The founding of An Nuqayah marked the new beginning of long history of influence and dominance, not only as the result of the internal power of this elite group that would be discussed further below, but also because the social change in Sumenep in the 19th century made it easier for a new social elite group to burgeon.

Five years before Syarqawi found his pesantren in Guluk-guluk, the Sultanate of Sumenep was replaced by regency system as the Dutch colonial government moved forward with their direct role not only in Madura but across the East Indian archipelago. The last independent ruler of Sumenep, Panembahan Notokusumo, passed away in 1879, and his uncle was appointed the acting regent by the Dutch government, and in 1883 was formally inaugurated as the first colonial regent of Sumenep, although he still used the name Pakunataningrat as the last king did. ${ }^{24}$ The power of royal family declined, as now they did not have strong material base of power any longer. The upeti system was the main source of income for the royal family, and they could no longer rely on it since the direct government system and capitalist mode of production were engaged. ${ }^{25}$ The regents began to be paid by

22 de Jonge, Madura dalam Empat Jaman; Idem., "Perkembangan Ekonomi." The pesantren was formally established in 1952 by one of Chotib's sons, kyai Djauhari.

${ }^{23}$ Interview with kyai Syafi'i Ansori. I also would like to thank Ustadz Mumu Mubarak Omo (Perth) for helping me to find the English words with closest meaning to An Nuqayah. Please note that the name An Nuqayah was not used until mid-1930s. See Sitrul Arsyi et. al., Satu Abad an Nuqayab: Peran Pendidikan, Politik, Pengembangan Masyarakat (Sumenep: P.P. An Nuqayah, 2000), p. 1.

${ }^{24}$ Donald Tick, "The Rulers of Madura" (http://www.londoh.com/fotindo_madura_sumenep_1c.htm, created 2005).

${ }^{25}$ Kuntowijoyo, Perubahan Sosial dalam Masyarakat Agraris: Madura 1850-1940 (Yogyakarta: originally Social Change in an Agrarian Society: Madura, 1850-1940 (Unpublished Ph.D Dissertation, Colombia University 1980), translated into Indonesian by M. Effendhie \& P. Armariepuja, Mata Bangsa, 2002). Upeti is compulsory tribute paid by the people for the king; this system was widely used by the traditional rulers in feudalistic societies. 
the Dutch government with monthly salary, and their influence over the people faded away very quickly. This social change within which the old hegemonic structure collapsed would significantly pave the way for religious elite to develop their social significance, 26 in which Syarqawi and An Nuqayah played a very central role.

\section{Pillars of the Genealogical Network}

Whereas the superiority of the religious elite over the mass had been mainly based on the educational excellence, their ability to exploit social change would require some additional means that included a strong and effective network. Syarqawi eventually was able to be on the forefront: the most important aspect of the Bani Syarqawi as an elite group has been its genealogical network. The fact that Kyai Syarqawi was a polygamist seemed to have contributed to this.

All written and oral sources confirm that Syarqawi had more than one wife. There are some disagreements amongst the references regarding the wives of Syarqawi, ${ }^{27}$ but the sources seem to agree that Syarqawi have another wife in Kudus, and up two three other wives in

26 As Mansurnoor puts it: "The decline of rato [lit. king] in the face of colonial intrusion helped many ulama to share the rato's prestige at the local level." Mansurnoor, Ulama of Madura, p. xviii; cf. Iik A. Mansurnoor, "Rato and Kyai in Madura: Are They Twins?," in Kees Van Dijk, Huub de Jonge, and Elly TpuwenBouwsma (ed.), Accross Madura Strait: The Dynamics of Insular Society (Leiden: KITLLV Press, 1995).

27 Bisri Effendy says that Khadijah was Syarqawi's first wife, and he married the second wife in Kudus when he and Khadijah visited the town; see Bisri Effendy, Annuqayab: Gerak Transformasi Sosial di Madura (Jakarta: P3M, 1990), p. 56. The later sources, including the family tree book of Bani Syarqawi, indicated that Syarqawi had already had a wife in Kudus when he started his teaching activities in Prenduan. See Muhammad Naqib Hasan et al., Silsilah K. H. Moh. Syarqawi Al-Kudusi, Pendiri Pondok Pesantren an Nuqayah, Guluk-Guluk, Sumenep, Madura (Sumenep: IPBS, 1999), p. 4. Cf. Arsyi et al., Satu Abad an Nuqayah, p. 2. Controversy is also found regarding the children of Syarqawi. Effendy says that Syarqawi had child/children with each of his wife, except with Sarbati, the forth one. Quite contrary to that, Hasan writes that Syarqawi did not have child from his marriage with Khadijah. See Effendy, Annuqayab: Gerak Transformasi Sosial, p. 56, Hasan, Silsilah K. H. Moh. Syarqawi Al-Kudusi, p. 161. It is not very easy to decide which version to accept, mostly because the works on the life and the early family line of Syarqawi are to a large extent based on oral stories. However, given the more detailed data available in the later sources (including the years of birth of many people aggregated in the family tree book), the version that Syarqawi had already had a wife in Kudus before marrying Khadijah, and that he had child/children with each of his wife, is more acceptable. 
Sumenep after Khadijah. However he was not married to more than four wives in a time, because he seemingly married the fifth and the sixth wives after the earlier wives passed away. With the total six wives, Syarqawi had 25 children both in Kudus and Sumenep. ${ }^{28}$ It is not an exaggeration to say that, with all these, Syarqawi was apparently ready to start the huge genealogical network that would later prove to be powerful. ${ }^{29}$

The main pillars of this network were established around the old line that Syarqawi started with when he began to teach in Guluk-guluk. In the fifth year the number of santri (student) studying at his pesantren had reached as many as 100 people, living in no less than 12 lodgings in an area called Dhalem Tenga (lit. central building). When Syarqawi passed away in 1910, the leadership of this yet anonymous pesantren was continued by Bukhori and Idris, his sons with Khadijah. Syarqawi's son-in-law Imam from nearby Karay village (husband of Syarqawi's daughter with Khadijah, Zubaidah), also helped the brothers managing their pesantren.

In these early stages, the seeds of competition amongst the descendents started to grow, partly between the sons of Syarqawi from different mothers. By 1920s, some of Syarqawi's sons with Qamariyah came back from their education at pesantren across Madura and Java, and also from Middle East, and brought some important changes to Syarqawi's heritage. First and the very obvious change was the beginning of what would later form the confederation of An Nuqayah. In 1917, Ilyas found his own pesantren in adjacent area to Dhalem Tenga, known as Lubangsa. In the same years, a bit physically farther apart from Dhalem Tenga, another pesantren named Al Furqan was established by a son-in-law of Syarqawi, Hussaini (husband of Aisyah), in Sabajarin. Five years later, Ilyas' younger brother Abdullah Sajjad also came back to Guluk-guluk, and found another pesantren in area that would later be known as Latee, due east of Lubangsa. Dhalem Tenga seemed to decline after the coming back of Ilyas and Abdullah

\footnotetext{
${ }^{28}$ The names, year of birth and inter-marriage relationship will mostly refer to Hasan, Silsilab K. H. Moh. Syarqawi Al-Kudusi.

${ }^{29}$ Genealogical network has been one of the main features of pesantren network, with various bases, ranging from the bloodline to inter-marriage network. See for example Zamakhsyari Dhofier, The Pesantren Tradition: The Role of the Kyai in the Maintenance of Traditional Islam in Java (Arizona: Program, 1999).
} 
Sajjad. Idris, half brother of these two young kyai, then moved to a nearby village Kalabaan and continued to teach his santri here.

Another important change was the introduction of madrasi system as an addition to the sorogan and wetonan systems that had been in use since $1887 .{ }^{30}$ The madrasi system was introduced in 1935 by Khazin, son of Ilyas. It was also around this year that the name An Nuqayah started to be used, as a holding institution of the Lubangsa, Al Furqan, and Latee pesantren.

During the next 20 years there was no significant change to An Nuqayah, until in 1963 Hasan Bashri, Ilyas' son-in-law established another pesantren in the Nirmala area and become the new part of An Nuqayah. Hasan Bashri has a more opened vision on the madhhab (schools of religious law), and unlike the other kyai from An Nuqayah, he did not take Sha ipath as the superior madhhab. ${ }^{31}$ Nine years after the founding of Nirmala, another pesantren was established in Lubangsa Selatan by Ishomuddin, son of Abdullah Sajjad, younger brother of Basyir who runs the Latee pesantren after the death of his father during the Indonesian revolution for independence.

Apart from the five pesantren as the elements of An Nuqayah confederation, several other pesantrens were founded by Syarqawi's sons-in-law (many of them were santri at An Nuqayah, or sons of kyai from other pesantren) or their descendants, which form the complex network and competition of this religious elite group. It is certainly important to underline that the santri of An Nuqayah have also spread either to come back to their home pesantren or to establish the new one, and contributed to this network. From the first generation, one of Syarqawi's sons-in-law, Imam, was the root of one of the extended parts of the genealogical network. Imam's daughter was married to kyai

\footnotetext{
${ }^{30}$ Madrasi is a system similar to that applied in modern educational institutions where the santri were divided into classes. Sorogan and wetonan are traditional methods to study the kitab kuning (traditional Islamic literature that has been the main sources in pesantren). Sorogan is more individual where santri read the kitab kuning independently under the supervision of kyai. In wetonan the kyai teach the kitab kuning to the group of santri periodically. Some sons and grandsons of Syarqawi were trained at Tebuireng pesantren in Jombang and were inspired by the application of madrasi system at Tebuireng since a couple of years before.

${ }^{31}$ Hasan, "Pola Pembangunan," p. 168. We will discuss later that kyai from Nirmala was in a political alliance with PAN (Partai Amanat Nasional, a political party with the modernist Muslim Muhammadiyah communities as the main social base) in the Bupati election.
} 
Ali Wafa from the coastal village of Ambunten. In the next generation, this pesantren (now the Al Aswaja) would become politically important, partly because of his access to the kepulauan area from which the majority of its santri come from. ${ }^{32}$ The current important kyai from this line is Unais Ali Hisyam. From the second generation, the daughter of Ilyas, Badi'ah, is married to kyai Siradjudin who was a santri at An Nuqayah and later found Nurul Islam pesantren in Bluto, a village due south of Guluk-guluk. This part of network is also politically important, as a son of Siradjudin, Ramdlan, is now the Bupati (District Head) of Sumenep.

\section{Long Journey to Legal-Rational Authority}

Education and community empowerment have always been the central contribution of pesantren such as An Nuqayah. Today An Nuqayah has every level of formal education from primary school to college. Affordability of educational cost, and most certainly the full time interaction with the kyai and other santri in a religious environment, must have been the main reason for parents to send their children to this institution. The community development has also been part of An Nuqayah with, for instance, the BPM (Biro Pengabdian Masyarakat, the community service bureau) that has brought An Nuqayah to wider social network across the nation, and gave it Kalpataru award in 1981.33

Involvement in political activities has been initiated since the first generation of the Bani Syarqawi. The first formal political position of the Bani Syarqawi was achieved during the Indonesian revolution for independence, an era when many kyai and santri from pesantren across the town were involved in some militias, including Sabilillah that was the militia wing of Masyumi (Majelis Syuro Muslimin Indonesia, a confederation of Indonesian Islamic organisation). Abdullah Sajjad, usually depicted to have strong leadership capability, was elected the klebun (village head) of Guluk-guluk in 1947. He was killed a couple of months later in a battle with the Dutch armed force who was coming to Sumenep to put the town under its siege.

\footnotetext{
32 Kepulauan literally means the archipelago, referring to 126 smaller islands situated due north-east of the mainland of Sumenep.

${ }^{33}$ Hasan, "Pola Pembangunan"; interview with Syafi'i Ansori. Kalpatura was award granted to individuals or institutions with great achievement in environmental conservation, during Soeharto administration.
} 
One of the seeds of political role of the Bani Syarqawi could be found in the role played by An Nuqayah during the establishment of NU (Nabdlatul Ulama) in Sumenep. Ilyas was the first chairperson of $\mathrm{NU}$ in Sumenep, inaugurated by the first national chairperson of NU kyai Hasyim Asy'ari himself in Guluk-guluk. However, considering the geographical position of Guluk-guluk, Ilyas handed over the position to kyai Abi Syuja' from the central area of Sumenep three months after the inauguration. ${ }^{34}$ An Nuqayah was also the central element of Masyumi when NU integrated to this organisation both as a social organisation prior to Indonesian independence and as a political party since 1945. When NU withdrew from Masyumi to become a political party in 1952, Ilyas and other kyais in An Nuqayah refused to leave Masyumi, even when Kyai Wahid Hasyim (leader of NU Party, son of Hasyim Asy'ari) wrote a personal letter asking him to move to the new party. ${ }^{35}$ Later on, Idris, supported by Ishomuddin, joined NU party. This would draw a political line in An Nuqayah, if covertly, between the kyai involved in Masyumi and those who were in NU party. However, when Masyumi was banned in 1960, and NU was integrated to PPP (Partai Persatuan Pembangunan) in 1973, the political line was getting more invisible.

During the New Order era, PPP was the only effective political means for the Bani Syarqawi. From the second generation there were Amir, Warits (both are sons of Ilyas), Muqsith (son of Idris), and Basyir; while from the third generations were Tsabit (son of Khazin) and Syafi'i Ansori (husband of Najahatin, a great-granddaughter of Syarqawi). Most of them were members of DPRD (Dewan Perwakilan Rakyat Daerah, the local council) of Sumenep, and Warits was also member of the National People's Consultative Assembly (MPR, Majelis Permusyawaratan Rakyat) 1992-1998. When in 1984 NU made the socalled 'return to khittah' decision and, partly repeating what it did in 1952, withdrew from PPP and gave up direct political role, elements of the Bani Syarqawi decided not to leave PPP, including Syafi'i and Warits (repeating his father's rejection to leave Masyumi in 1952) who would remain in the party in the post-New Order era.

\footnotetext{
34 Arsyi, Satu Abad an Nuqayah, p. 54. NU was found in Surabaya, 1926. Hasyim Asy'ari, the grandfather of former Indonesian President Abdurrahman Wahid, was the teacher of the first and second generations of Bani Syarqawi when they were studying at Tebuireng.

35 Ibid., p. 61.
} 
When the New Order collapsed, pillars of the authoritarian regime (especially the military, and the state-sponsored party, Golkar) are also challenged by the vast majority of the people. Sumenep during this era shared the nationally widespread enthusiasm to foster political change. The anti-TNI (Indonesian National Military) and, to a lesser extent, anti-Golkar feeling were dominant issues in the 1999 general election and 2000 bupati election. Elections that during the New Order era were merely pesta demokrasi (the democratic festivity), now turned into more open political contestation and could be used to push elite circulation. This opportunity was taken by pesantren-connected actors to take over the power from Golkar, and make the party significantly declined since the 1999 general election. The founding of PKB (Partai Kebangkitan Bangsa, sponsored by NU) was surely a big challenge for Golkar. As the result of 1999 general elections, PKB over took Golkar's domination in DPRD, and brought some kyai into the council. With 25 of 45 seats in total, PKB was now the majority, and its leader, Kyai Busyro Karim, was later elected speaker of the local council. Many members of the Bani Syarqawi were elected, including Hazmi (son of Basyir), Syafi'i, Muhsin (son of Amir), and Baihaqi Syafiuddin (Syarqawi's great grandson from Khadijah line).

Busyro, a kyai from pesantren $\mathrm{Al}$ Karimiyyah in Gapura, was in the top position in PKB Sumenep branch since its declaration in 1999 until he was replaced by Kyai Unais Ali Hisyam (Ambunten) in 2007. He represents the non Guluk-guluk background (sometimes also called the kota connection), ${ }^{36}$ with a majority of PKB members in DPRD having a Guluk-guluk background. With this powerful strategic alliance, $\mathrm{PKB}$ was ready to move, when the time came for the local council to elect a new Bupati. With the legislative top job being in the hand of kyai from kota, the natural process in the triangle would now look for those with one to fill the leadership position in executive. With the support of majority of its sub-branch boards, PKB came to a decision to nominate Kyai Ramdlan Siradj from Nurul Islam pesantren, head of the advisory council (syuriab) of NU Sumenep branch, in the Bupati election.

While the decision to nominate Ramdlan for Bupati position was made without much quarrel, PKB seemed to have some difficulties to

\footnotetext{
${ }^{36}$ Kota literally means city; it refers to kyai in the central area of Sumenep, normally as opposed to the Guluk-guluk connection a.k.a. the Bani Syarqawi.
} 
determine the right person to be his running partner. Realising that its candidate for Bupati had no political experience, let alone the bureaucratic skill to govern, PKB had considered picking one of the senior bureaucrats in Sumenep to be nominated as the Wakil Bupati (vice head of district). It was in this stage, however, that one could observe the early sign that the hidden political rivalry amongst kyai was now becoming more overt. In the early stage, PKB started with a list of senior bureaucrats to be nominated to the second executive position. By the behest of Basyir who is a cousin of Ramdlan's mother and the head of PKB advisory council, the party recruited a number of people to perform istikharath (a prayer to seek the guidance of the God in a situation of problem to which no solution is apparent) under the direct supervision of Basyir. ${ }^{37}$ The team was later called tim istikharah, and was apparently not able to finish the job, partly because the manoeuvres of some kyai disinclined it to make a decision that was politically controversial. An important issue at the time was the campaign for ABG (asal bukan Guluk-guluk, 'anything but not Gulukguluk') - a campaign organised by those who wanted the vice Bupati position for people with non Guluk-guluk background. One of the very blatant manifestations of it was when kyai Said Abdullah from pesantren Mathali'ul Anwar in the central Sumenep raised the name of his brother in law, Muis Aliwafa, to the vice Bupati candidate market. Muis, at the time a head of sub-district in Lamongan, is the cousin of PPP leader, Annisah, and his wife is Busyro's cousin. This made him an ideal candidate because he is part of the kota connection. Muis was not popular at the time, but since the top executive leaderships were elected by the local council, popularity of candidates was not a big issue.

With the pair of candidate --carrying out pesantren' interest in the political process-- PKB was now ready to compete in the Bupati election. But it was not until it passed the last test could PKB win the election. The incumbent Bupati Colonel Soekarno Marsaid was running for a second term of 2000-2005, and seemed to have managed to get rid of Police Superintendent Madjid Tawil from PPP's nomination for candidate. ${ }^{38}$ Without Madjid in the candidate list, the competition was simpler. Nevertheless, with anti-TNI feeling expressed widely by civil

\footnotetext{
${ }^{37}$ Radar Madura, April 19, 2000.

38 Suara Indonesia, April 28, 2000; Surya, April 28, 2000; Radar Madura, May 2, 2000.
} 
society elements, ${ }^{39}$ the incumbent understood that he was not able to rely on Golkar and the TNI-fraction any longer. He was then reported to offer some money, ranging from IDR 150 million to 300 million for PKB members of DPRD to vote for him. ${ }^{40}$ This was a big issue in the media, and PKB's reputation was surely at risk. It was responded to by $\mathrm{PKB}$ with the so-called 'political quarantining' of PKB members of local council in the house of young, charismatic Kyai Rahem Usymuni for two nights prior to the Election Day on 3 May 2000.

The idea of a political quarantine came from Basyir. Rahem, an eccentric kyai who was renowned by his supernatural ability, supported the idea and seemed to offer his house as the quarantine spot. His house, located inside the pesantren Tarate complex, was an ideal place for the pre-election quarantine given that it was located less than two kilometres from the DPRD building-literally 'behind' the local council. In this house, all 25 PKB members of DPRD stayed around the clock for no less than 48 hours. They were required to make an oath to vote for Ramdlan, and were implicitly threatened by serious personal and political consequences if known to vote for the incumbent, or to receive money from him. On the Election Day they were escorted directly to the DPRD. ${ }^{41}$

This political manoeuvre evidently worked very effectively. Ramdlan won the election with 28 votes, and leaving only 12 for Soekarno Marsaid. One step of political change was complete. Now the pesantren had a stronger grip on the political process.

Madjid Tawil's candidacy via PPP in 2000 could be seen as a manifestation of the party's doubts. PPP has long been the rival of Golkar, and during the peak of New Order's political repression, the party was much oppressed, especially at the time of 1982 Election where the government adopted a very abrupt attitude toward its political opponents. In 1999, when PPP's political rivalry with Golkar was taken over by $\mathrm{PKB}$, the party lost its traditional theme and was

\footnotetext{
39 Radar Madura, April 11, 2000.

40 Arus Reformasi, April 5, 2000; Radar Madura, May 2, 2000; Information on the amount of money, equal to $\$ 15,000$ to 30,000 , was acquired from some kyai.

41 Suara Indonesia, May 4, 2000; Interviews with Kyai Rahem Usymuni and Mawardi. Rahem Usymuni is the son of one of the most influential kyai in the cluster, the late Kyai Usymuni. He implicitly admitted that the mafia-style method involved in the political quarantine was his idea.
} 
politically disoriented. Madjid's candidacy was a blunder that would be best understood in this way.

PPP has become more firm in its political goals since 2001, when Warits returned to Sumenep political stage and led the party. He then ran for Sumenep DPRD membership in the 2004 Election. Warits, a very experienced politician, was later proven to be a huge political threat for PKB politicians. Led by Warits, PPP's seats in DPRD rise from six in 1999 Election to 7 in 2004, whereas PKB declined from 25 to 23. Warits political artfulness would also be proven later in the first direct election of Bupati.

In his first term of office, Ramdlan was not able to effectively control the bureaucracy. Corruption was far from being removed from the bureaucratic performance. This has made many kyai feel that the district government was getting worse under political leadership of a kyai-a view that was shared with other civil society elements including the press. On the other hand, Ramdlan also failed to maintain good communication with other kyai that supported his candidacy in 2000. The senior kyai were frustrated by the fact that their access to the Bupati was obstructed by both bureaucratic procedures and Ramdlan's unwillingness to listen to their advice. Many kyais now shared the view that having a kyai as a political leader meant nothing unless he could carry out the ibadab values in his power performance. ${ }^{42}$

Echoing the more general tendencies in local government practices in the country since 1999, Sumenep also showed a growing tension between executive and legislatures. ${ }^{43}$ In this town, the executivelegislative tension has also had another outlook: emulation between Kota and Guluk-guluk clusters. Busyro has become the biggest political rival for Ramdlan. Any DPRD's criticism of the Bupati would to some extent be taken as Busyro's political enmity of Ramdlan, partly because

\footnotetext{
${ }^{42}$ Interviews with Kyai Said Abdullah, Kyai Wadud Munir (An Nuqayah), and Rahem. Surabaya Post, February 16, 2005, Bhirawa, March 3, 2005. Ibadah means good deeds in accordance with religious obligations.

${ }^{43}$ Legislative bodies during the New Order era were often called 'rubber stamp' for their limited political power to merely giving formal legitimacy for executive's policies. This has changed since 1998, where political pendulum has swang to the legislative side, and created some tensions with executive bodies.
} 
it has become publicly known that Busyro wanted to run for the top executive position in the forthcoming election. ${ }^{44}$

Busyro could actually take advantage of Ramdlan's declining popularity, but he had a problem in gaining support from senior kyai. Busyro is a young and brave kyai, but his assertiveness was sometimes deemed as arrogance by some senior kyais. To some people, Busyro lacked tawaddif (lit. humility), a character that is expected from a kyai, and an important élan in NU. Even kyai from Kota would not see him as an ideal figure to represent kyai in politics. ${ }^{45}$ Nevertheless, with his position in PKB, Busyro was able to ensure his candidacy in the Bupati direct election. Basyir, apparently being bound to his formal position in PKB, showed support of Busyro's candidacy.

Following the internal process to find the most popular candidate, PKB came to decision to give its ticket to Busyro, with Tsabit from An Nuqayah as the running partner. Tsabit was later disqualified from the candidacy process because his formal education background was lower than the minimum requirement; he was replaced by Ramli, a Sumenepborn bureaucrat from Jember. Elements in PKB was actually still hoping that Ramdlan would run for the next term of office using the party's ticket, but the incumbent always said that he was not interested to be in the position any longer, ${ }^{46}$ and was reported to have made a statement that being in the pendopo felt like in hell for him..$^{47}$ In fact, Ramdlan never applied for any parties' ticket to run for Bupati candidacy. In the earlier stage, PPP seemed to assume that Ramdlan would still be with $\mathrm{PKB}$, and therefore waited for PKB's decision. Warits indicated that if PKB had nominated Ramdlan, PPP would have supported it. ${ }^{48}$ It was now obvious that bringing Ramdlan to the Bupati election was PPP's main objective, for a very clear reason: Warits' had calculated that Ramdlan as the incumbent would have the biggest chance to win the election. By supporting his candidacy, PPP would make a great investment for its own political goal, especially for

\footnotetext{
44 This has been his ambition since 2000, and, Busyro indicated, a goal for 2010. Interview with Kyai Busyro Karim.

45 Interviews with Rahem and Said.

46 Interview with Kyai Ramdlan Siraj.

${ }^{47}$ Interviews with Mawardi, Unais, and Syafi'i. Pendopo is the official residence of the Bupati.

48 Teropong, September 14, 2004. Interview with Warits.
} 
the next 2009 general election. Ramdlan's hesitation to run would only be a minor problem for PPP with its existed kyai network having been politically rejuvenated by Warits. By the exhortation of Kyai Hammad Karay, a much respected and charismatic kyai from a nearby village of Guluk-guluk, Ramdlan was finally convinced that his second term of office would be the best for the people of Sumenep. Hammad was reported to tell Ramdhan that if he would not run for the election, he would be (lit. cruel) to the Sumenep people, particularly his supporters. ${ }^{49}$

Initially, PPP chose Artawi Sahari as Ramdlan's running partner. Following the rejection by majority of sub-branch boards of PPP, Artawi was dropped from nomination, and PPP took a senior bureaucrat from Bangkalan, Mochammad Dahlan. The official explanation had been that Artawi was not able to comply with some administrative requirement of the candidacy, ${ }^{50}$ but the real reason was that PPP needed to response properly to the growing demand to accommodate people from kepulauan. Dahlan was born in Arjasa Island, and would be the best person to ensure the support from kepulauan, given the fact that PPP most likely was not able to rely on the support from Ambunten cluster to gain vote from the kepulanan, because of Unais' position as the Secretary of PKB that was a formal binding for his support of Busyro's candidacy.

Busyro and Ramdlan had been the strongest candidates since the very beginning, but the political contestation would also become more complicated by the tight competitions with other candidates: Muis (the vice Bupati), Afif Hasan (son of Hasan Bashri from Nirmala pesantren in An Nuqayah), and Madjid Tawil, who this time took Kyai Wakir Abdullah (leader of Golkar) as his running mate. Afif, affirming Nirmala's inclination toward modernist Islam, used PAN ticket in the candidacy. With all five pairs of candidates having kyai element, this election was applauded as a battle of kyai; some people said, looking at the fact that level of competition among the sons and grandsons of Syarqawi is very high, the candidacy process was 'the battle of the Bani Syarqawi'. This battle was won by Ramdhan who gained $44.08 \%$ of the total vote.

\footnotetext{
${ }^{49}$ Interviews with Syafi'i and Warits.

50 Radar Madura, April 15, 2005.
} 


\section{Conclusion}

By the year 2010, Ramdlan will be ten years in Bupati position; Other Bani Syarqawi figures who are members of DPRD will be in the position for at least five years (except for Warits who has a much longer record in formal position). This means that in 2010 the Bani Syarqawi would have been dominating local politics of Sumenep for ten years, with significant achievement of the legal-rational authority to continue their traditional authority since 1887.

We have discussed in this article that their superiority over the mass has been mainly based on educational excellence and genealogical network that is both powerful and full of conflicts. The social significance of the superiority found its way through a social change that enabled the religious elite to be the dominant elite group in rural communities when the power of their royal counterpart declined rapidly. Every political change that took place in modern Indonesia would also pave the way for this elite group to transform its traditional to legal-rational, culminating in the latest political transition that brought members of this elite group to top political jobs at local level.

Elite theory, with national and formal tendency in its assumptions, has proven to be useful to analyse elite at local level with non-formal institution being its base. Combined with Weberian model of authority, the formalistic tendency of elite theory can be balanced with a perspective that elite can develop and exercise power over the mass even they are outside the formal structure of politics. []

\section{Bibliography}

\section{Books and Articles}

Arslan, D. Ali. "Elite Theory Applied to Contemporary Turkish Society." International Journal of Human Science, 2, No. 2 (2005): pp. 1-16.

Arsyi, Sitrul, et. al. Satu Abad an Nuqayah: Peran Pendidikan, Politik, Pengembangan Masyarakat. Sumenep: PP An Nuqayah, 2000.

Aspinall, Edward. Opposing Suharto: Compromise, Resistance, and Regime Change in Indonesia. California: Stanford University Press, 2005.

Bulliet, Richard W. The Case for Islamo-Christian Civilization. New York: Columbia University Press, 2004. 
Burleigh, Michael. Earthly Powers: The Clash of Religion and Politics in Europe from the French Revolution to the Great War. California: Harper Collins, 2006.

Casanova, Jose. "Civil Society and Religion: Retrospective Reflections on Catholicism and Prospective Reflections on Islam." Social Research, 68, No. 4 (2001): pp. 1041-80.

de Jonge, Huub. Madura dalam Empat Jaman. Jakarta: Gramedia, 1989.

-. "Perkembangan Ekonomi Dan Islamisasi di Madura." in Huub de Jonge (ed.). Agama, Kebudayaan, Dan Ekonomi: StudiStudi Interdisipliner Tentang Masyarakat Madura. Jakarta: Rajawali Press, 1989.

Dhofier, Zamakhsyari. The Pesantren Tradition: The Role of the Kyai in the Maintenance of Traditional Islam in Java. Arizona: Program, 1999.

Effendy, Bisri. Annuqayab: Gerak Transformasi Sosial di Madura. Jakarta: P3M, 1990.

Emmerson, Donald K. Indonesia's Elite: Political Culture and Cultural Politics. Ithaca: Cornell University Press, 1976.

Etzioni-Halevy, Eva. "Network Governance as a Challange to Democratic Elite Theory." Paper presented at the Conference on Democratic Network Governance, Copenhagen, May 22-23, 2003.

Hague, Rod, and Martin Harrop. Comparative Government and Politics: An Introduction. $5^{\text {th }}$ edition. New York: Palgrave, 2001.

Hasan, H. M. Afif. "Pola Pembangunan Masyarakat Desa Oleh Pondok Pesantren an Nuqayah." Unpublished MA Thesis, IKIP Malang, 1995.

Hasan, Muhammad Naqib, et. al. Silsilah K.H. Moh. Syarqawi Al-Kudusi, Pendiri Pondok Pesantren an Nuqayah, Guluk-Guluk, Sumenep, Madura. Sumenep: IPBS, 1999.

Hay, Colin. Political Analysis: A Critical Introduction. New York: Palgrave, 2002.

Haynes, Jeff. Religion in Third World Politics, Issues in Third World Politics. Colorado: Lynne Rienner, 1994.

Heywood, Andrew. Politics. New York: Palgrave, 2002. 
Kingsbury, Damien, and Arief Budiman (eds). Indonesia: The Uncertain Transition. Adelaide: Crawford Publishing, 2001.

Kuntowijoyo. Perubahan Sosial Dalam Masyarakat Agraris: Madura 18501940. Yogyakarta: originally Social change in an agrarian society: Madura, 1850-1940, Unpublished Ph.D Dissertation, Colombia University (1980), translated into Indonesian by M. Effendhie \& P. Armariepuja, Mata Bangsa, 2002.

Mansurnoor, Iik A. Islam in Indonesian World: Ulama of Madura. Yogyakarta: Gadjah Mada University Press, 1990.

---------. "Rato and Kyai in Madura: Are They Twins?." in Accross Madura Strait: The Dynamics of Insular Society, edited by Kees Van Dijk, Huub de Jonge and Elly Tpuwen-Bouwsma. Leiden: KITLLV Press, 1995.

McGibbon, Rodd. "Indonesian Politics in 2006: Stability, Compromise and Shifting Contests over Ideology." Bulletin of Indonesian Economic Studies, 42, No. 3 (2006): pp. 321-40.

Nyman, Mikaela. Democratising Indonesia: the Challenges of Civil Society in the Era of Reformasi. Copenhagen: NIAS, 2006.

Tomsa, Dirk. "'The Defeat of Centralized Paternalism: Factionalism, Assertive Regional Cadres, and the Long Fall of Golkar Chairman Akbar Tandjung." Indonesia, 81 (2006): pp. 1-23.

Törnquist, Olle. "Dynamics of Indonesian Democratisation." Third World Quarterly, 21, No. 3 (2000): pp. 383-423.

--------. 'What's Wrong with Indonesia's Democratization?." Asian Journal of Social Science, 30, No. 3 (2002): pp. 547-69.

\section{Electronic Sources}

Reynolds, H. T. "The Power Elite." (http://www.socialstudieshelp.com/APGOV_Power_Elite.htm, created 1996).

Tick, Donald. "The Rulers of Madura." (http://www.londoh.com/fotindo_madura_sumenep_1c.htm, created 2005).

http://www.sociosite.net/topics/weber.php

http://ssr1.uchicago.edu/PRELIMS/Theory/weber.html. 


\section{Newspapers}

Arus Reformasi. April 5, 2000.

Bhirawa. March 3, 2005

Radar Madura. April 11, 2000.

- April 19, 2000.

April 15, 2005.

---------. May 2, 2000.

Suara Indonesia. April 28, 2000.

----------. May 4, 2000.

Surya. April 28, 2000.

Surabaya Post. February 16, 2005.

Teropong. September 14, 2004.

\section{Interviews}

Interview with Kyai Busyro Karim.

Interview with Kyai Ramdlan Siraj.

Interviews with Kyai Rahem Usymuni

Interviews with Kyai Said Abdullah.

Interviews with Kyai Wadud Munir.

Interviews with Mawardi.

Interviews with Unais.

Interviews with Syafi'i.

Interview with Warits. 